\title{
HELIODOR EOBAN HESSE, O CO-FUNDADOR DO RIO DE JANEIRO $(*)$.
}

\author{
HELMUT ANDRA \\ Da Sociedade de Estudos Históricos. \\ I
}

A descoberta de um Continente desconhecido ou de uma grande ilha no sudoeste do Atlântico, que cada vez mais se abria perante os audaciosos navegadores portuguêses, não produzia na côrte de Portugal o eco que alguns anos atrás a descoberta de terras no noroeste daquele oceano, por Colombo, tinha causado. As expectativas que dantes se ligavam às Indias Ocidentais, à "India" do genovês, continuavam a não se realizar e pareciam ilusões, e assim afigurava-se aos soberanos da Lusitânia que Deus teria abençoado sòmente as terras do Extremo Oriente - com especiarias preciosas, minérios raros e pedras brilhantes - e ignorado as outras, banhadas pelo Atlântico; pois a própria África, ao leste do Nôvo Mundo, cuja região costeira os portuguêses tinham sondado até ao Cabo das Tormentas, e até mais para o nordeste, não parecia ser uma área rica, onde abundassem as preciosidades cobiçadas pelos europeus. E por isso mesmo a corôa de Portugal encarava a sua nova possessão americana, a Terra de Vera Cruz, meramente como um bem-vindo ponto de apôio ou base para as esquadras que seguiam para a India ou dela regressavam, e como fornecedora do pau-brasil - valioso mas não digno de ser comparado às riquezas da India. De resto, considerava-se justo não dispersar os recursos, aliás limitados, de Portugal em relação a homens, barcos e dinheiro, mas sim juntá-los em benefício das rotas do Oriente. $\mathrm{O}$ rei limitava-se assim a entregar às iniciativas privadas o comércio com os nativos, assim como a exploração e defesa da zona costeira; e finalmente a dividir o território um capitantas hereditárias, com a esperança de assim assegurar a sua exploração comercial, o seu povoamento, a sua colonização e defesa. Até aos meados do século XVI, porém, êsses donatários, caso fizessem de

(*). - Na oportunidade das comemoraçōes do IV Centenário da fundação da cldade de Săo Sebastláo do Rio de Janeiro (20-1-1966), justifica-se, com a devida autorizaçáo da Revista Humboldt, a publicação do presente artigo, editado no seu n̊ 13, págs. 59-67, de 1966 (Nota da Redą̧ão). 
um modo geral esforços sinceros no sentido de materializar as expectativas do rei, tiveram de reconhecer que, quase sem exceções, tinham êsses esforços sido malogrados: a maioria tinha perdido, em quantidades consideráveis, dinheiro, produtos e bens, se não a própria vida. Apenas no nordeste do território, na região à volta de Recife-Olinda (Pernambuco), e no sul, perto de São Vicente (São Paulo), tinham surgido centros econômicos notáveis, que pareciam oferecer perspectivas boas, graças ao desenvolvimento da cultura de cana-do-açúcar e a produção do açúcar pròpriamente dito. A essas regiões juntou-se então a área de Salvador (Bahia) cuja administração foi por fim assumida pela corôa, e onde esta estabeleceu a sede de administração para as colônias (em 1548), depois de verificar que os esforços dos donatários eram mal-sucedidos.

Foi só na segunda metade do século XVII que o Brasil se tornou o ponto central da política colonial portuguêsa, isto é, após o país ibérico ter perdido a maior e mais importante parte das suas possessões ultramarinas - acima de tudo na Ásia, para os holandeses, inglêses e franceses - durante o período da sua união à corôa da Espanha (1580-1640). Cem anos antes surgira pela primeira vez a necessidade de fazer frente, militarmente, às tentativas de potências estrangeiras de se estabelecerem e instalarem um finca-pé no Brasil. As duas nações irmãs da Ibéria, Espanha e oPrtugal, soberanas dos mares e dos oceanos no período das grandes viagens aos pontos mais distantes de além-mar, conseguiram que o Papa dividisse, em 1494, o mundo transoceânico em duas metades - uma que seria espanhola e outra portuguêsa, e que incluiriam regiões até então descobertas e outras ainda por descobrir. Os restantes estados europeus estavam, à medida que se tornavam mais fortes nos mares, menos dispostos a aceitar essa divisão do globo, e o mais cristão de todos os soberanos, Francisco I, rei de França, em breve se fêz ouvir: "Mostrem-me o testamento de Adão!"

Foram também os franceses e entre êles principalmente mercadores normandos e bretões, que poucos anos após a descoberta do Brasil, procuraram atingir a costa brasileira, o que de fato conseguiram: e ali estabeleceram feitorias, nas baías mais escondidas, e com vigor se dedicaram ao comércio com os indígenas. Já que a India fabulosa lhes fôra negada, contentaram-se com o pau-brasil, assim como com papagaios, macacos e outras coisas do mesmo gênero. Entendiam-se melhor com os índios do que os portuguêses, pois não utilizavam os selvagens como mão-de-obra. Encontravam-se os comerciantes franceses nas regiões desde o extremo norte até às áreas à volta de São Vicente; competia aos donatários, aos senhores de engenhos e às fôrças expedicionárias, raramente enviadas por Prtugal, 
descobrir os sítios dominados pelos franceses e destroçá-los. Era uma luta sem clemência. Mas uma ameaça muito grave aos direitos de Portugal surgira sòmente quando, além dos negociantes também políticos e homens de estado da França começaram a dedicar a sua atenção àquela nova região do Atlântico Sul e ali queriam estabelecer uma colônia francesa - La France Antarctique, que serviria ao mesmo tempo de refúgio para os calvinistas franceses. A história desta tentativa francesa desviar-nos-ia completamente do nosso tema; chamamos a atenção para a contribuição de Martin Begrich no $5^{\circ}$ tomo do Staden-Jahrbuch, onde o leitor encontrará mais pormenores (1).

A construção de um forte francês na ilha hoje conhecida pelo nome de Villegaignon, na Baía de Guanabara, foi uma provocação que Portugal não podia aceitar em silêncio. Já antes do estabelecimento dos franceses tinham os portuguêses reconhecido o valor estratégico da baía do Rio de Janeiro. E já em 1560 tinha o superior jesuíta Manuel da Nóbrega recomendado ao Infante cardeal Dom Henrique a construção de uma nova cidade naquela baía para a proteção das capitanias de São Vicente e do Espírito Santo; também o governador-geral Tomé de Sousa (1549-1553) considerava necessário o estabelecimento de uma povoação naquele sítio como base de defesa da colônia, e evidencia-se o fato de ter a regente de Portugal, Catarina de Áustria, dado ordens nesse sentido, quando as primeiras fôrças foram enviadas para expulsar os franceses. Essas fôrças consistiam principalmente de tropas auxiliares da Bahia, Espírito Santo e principalmente de São Vicente; contentaram-se porém em destruir a fortaleza francesa e expulsar os intrusos que em pouco tempo se reuniram e novamente se estabeleceram na baía. Com os poucos homens enviados por Portugal, porém, não era possível estabelecer um ponto de apoio ou base, e menos ainda uma povoação; e os habitantes de Olinda, Bahia e São Vicente, núcleos ainda reduzidos e novos, encaravam a saída dos colonos ativos como um enfraquecimento grave das suas comunidades. O êrro cometido em 1560 tornou porém necessária uma nova campanha contra os franceses, campanha essa que, após duras lutas de 1565 a 1567 , resultou numa expulsão definitiva dos hóspedes indesejados e conduziu à formação de uma nova povoação - nada menos do que o embrião de uma das mais belas cidades do mundo, "a mui leal e heróica cidade de São Sebastião do Rio de Janeiro". Aceitou-se o dia 10 de março de 1565 como o dia da fundação daquela cidade que, assim, tem agora uma história de 400 anos. Como das vêzes anteriores, também em 1565 se tornou necessário chamar os brancos estabelecidos na Bahia, no Espírito Santo e em São Vicente, assim como os seus amigos índios e mestiços, para a limpeza e conquista da baía, visto as fôrças enviadas para êsse 
fim por Portugal não serem suficientes. A fundação do Rio de Janeiro, que correspondia a uma pura necessidade militar, foi assim uma obra comum das maiores povoações que então existiam no Brasil. Predominante foi a participação dos povoadores de São Vicente, de seus colonos e seus sequazes. Reuniu-se assim em São Vicente, nos anos de 1560, 1565 e 1567 o grosso das fôrças portuguêsas; e um dos mais eminentes e distintos chefes nessas campanhas foi um alemão, Heliodor Eoban Hesse, que aparece geralmente nos documentos brasileiros muito simplesmente como Heliodoro Eobano. Ele chefiou numa altura fôrças auxiliares vicentinas e numa outra vez guerreiros índios e mestiços. Distinguiu-se nas lutas pela baía em 1560, 1565 e 1567 , assim como na expulsão dos franceses de um dos pontos de apôio mais ao norte, junto do Cabo Frio (onde, segundo alguns autores, teria perecido em 1568), e assumiu, nas décadas que se seguiram, elevados cargos na administração da comunidade. Quem foi êste co-fundador do Rio de Janeiro? O que sabemos acêrca de sua família?

Heliodor Eoban Hesse nasceu em Nuremberg, provàvelmente no ano de 1529 , pois a sua idade, afirmava-se, era de 11 anos quando o seu pai morreu em 1540. Era filho de Helius Eobanus Hessus, então professor de retórica e de poesia no liceu daquela cidade e nasceu provàvelmente do terceiro casamento do professor. O humanista, nascido em 6 de janeiro de 1488, era já muito conhecido no tempo de sua permanência em Nuremberg; era considerado um grande talento na poesia; os mais distintos intelectuais da sua época eram seus amigos, conhecidos ou correspondentes - nomeadamente Lutero, Reuchlin, Erasmo de Roterdam, Melanchton, Ulrich von Hutten, Rufus, Spalatin, Micyllus, Camerarius e Draco ou Draconites. A sua fama ultrapassava as fronteiras do Império Alemão, de modo que ainda 250 anos após a sua morte um dos seus biógrafos o designou como "sábio afamado também no estrangeiro" (2, pág. XII) . Ainda em 1874, surgiu uma nova biografia (3) do humanista, e em 1879, isto é, cêrca de 340 anos após a sua morte, foram as suas obras novamente editadas em dois volumes (4). Eobanus Hessus, que nunca se servia da língua alemã nas suas obras (existe uma só carta escrita por êle em vernáculo), é, ainda hoje, conhecido nos círculos especializados, e é, segundo parece, julgado demasiado severamente, como acontece na Biografia Geral Alemã (na Allgemein Deutsche Biographie). Criticam-no particularmente 
"pelo seu gracejo ou leviandade com que encarava a 'realeza' poética que the foi atribuída por brincadeira"; e "como rei verdadeiro aceitava as homenagens dos seus amigos, e fazia uso do título real com frequiência, chegando mesmo a aplicá-lo à espôsa e seus numerosos filhos" (5).

\section{O título de rei foi-lhe dado pelo grande intelectual Reuchlin que numa carta o considerou}

"o primeiro poeta da Alemanha" e a seguir aludiu ao significado grego do nome Hesse e o chamou "rei". Este nome 'Rex' foi-lhe em breve juntado ao seu pelos amigos, e deu-lhe oportunidade e ocasião para associaçōes muito agradáveis. Usava também, habitualmente, o título de 'Rex' nas cartas que escrevia aos seus familiares e dêles o acolhia por sua vez" (2, pág. 79-80).

Portanto, o sábio deve ter sido uma pessoa vaidosa. Mas até um intelectual como Erasmo, que não tinha qualquer tendência ou inclinação para lisonjas ou adulações, e gozava de uma reputação tão extraordinária que

"quem recebesse uma carta dêle considerava-se extraordinàriamente afortunado, pois uma tal carta tinha o valor de um diploma de sabedoria" (2, pág. 82),

escrevia em 1518 uma carta a Hessus que tinha nessa altura trinta anos de idade:

E pensava eu que já conhecia a Alemanha bem e sabia o que ela possui de intelectuais de renome... E vê lá, surge sủbitamente Hessus e mostra, em si só reunido tudo o que eu até hoje admirava ou gostava individualmente em vários! Pois o que revelam os teus poemas épicos senão um Ovidio cristão? Quem é bafejado pela Fortuna da leveza de uma expressão sem limites, igual à que tu demonstras de tôda a maneira e forma de poesia? A eloqüência acompanha, ligeira, a forma, e ambas são adornadas por uma devoção cristã. Na prosa surges de tal maneira que, quem o não soubesse, poderia pensar que essa é a tua especialidade - mas poeta, ao mesmo tempo, isso não! ó tu, gênio verdadeiro! $\mathbf{E}$ com o estilo está o caráter de acôrdo, nada mais puro e claro, nada mais simples e despretencioso, não, não há nada mais límpido. Ave rara, eminente sabedoria sem arrogância. O que poderia eu ainda desejar, meu sábio Hessus, a não ser um destino feliz que te possa corresponder aos magníficos dons que em parte deves ao teu trabalho e em parte deves ao Criador?" (6, pág. 220-221).

Eobanus deve ter sido um homem imponente; o jovem sábio é descrito da seguinte maneira: 
"A sua elevada estatura, a simetria de tôdas as partes do seu corpo, a fôrça viril combinada com uma formosura juvenil infundia, inspirava veneração e admiração; êle tinha uma fisionomia bela $\mathrm{e}$ máscula e, o que nessa época primorosamente adornava um homem, uma grande barba... A sua sincera devoção pela verdade e pela justiça tornava-o precioso para os amigos da virtude; tal o seu garbo e agilidade nas conversações em sociedade que todos os que estivessem perto dêle se sentiam tão bem, não havia qualquer receio de que alguém se pudesse ofender através do seu espírito alegre, porque acima de tudo êle exercia o máximo cuidado de não magoar ninguém. Dissimulações, astúcia e mentiras eram vícios que êle com razão designava de imperdoáveis e abaixo da dignidade humana' (2, pág. 19, 227 e 228).

Hessus nasceu num ambiente dos mais simples; o seu apelido verdadeiro não foi até hoje corretamente identificado. Enquanto alguns biógrafos lhe dão o nome paterno de Koch (isto é cozinheiro) (6) dizem outros que certamente o seu pai era cozinheiro e chamava-se Hans Göbbchen (7). Em qualquer dos casos, os seus pais eram serventes do convento de Heine ou Heina, em Hessen; a sua terra natal é, para uns, Bockerdorf, que pertencia ao mosterio e. para outros, Halgehausen ou Frankenburg - e Hessus mesmo assinava muitas vêzes Francobergensis. Foi em Frankenburg que êle recebeu as primeiras instruções nas ciências, e por isso êle tinha maior amizade por Frankenburg do que por Bockerdorf, onde seus pais se encontravam só para tratar de uns negócios quando êle nasceu (2, pág. 7). O prior do convento e uma família abastada em Gemünden, terra de sua mãe, tomaram a seu cargo o talentoso rapaz, deram-lhe a oportunidade de freqüentar a escola, e, mais tarde, depois de 1504, a Universidade em Erfurt, onde nessa mesma altura estudava também Lutero: Em 1508 obteve ali a licenciatura do magistério. A seguir partiu numa viagem que terminou em Riesenburg, onde se demorou na côrte do bispo Hiob von Dobeneck; e aqui adotou os três nomes que passaria a usar para a rubrica de seus poemas, Helius Eobanus Hessus - com os quais queria honrar a sua terra natal (Hessus), o santo do seu dia (Eobanus) e o domingo em que nasceu (Helius) (5); e seguiu em 1513 para Lípsia para ali se licenciar em direito, aceitando os conselhos e auxílio pecuniário do seu protetor o bispo que queria que êle se preparasse para mais tarde assumir funções na sua côrice. Hessus, porém, interessava-se mais pela ciência e viu-se obrigado a desistir dos seus estudos de leis, para os quais não sentia a menor inclinação. Aceitou o cargo de reitor do Instituto de Severi em Erfurt e pouco depois o professorado de retórica na Universidade da mesma cidade. Segundo Lossius.

"êle adquiriu uma aprovação extraordinária através das suas lições. A fama dêste grande poeta atraíu uma massa de jovens a 
Erfurt que se empurravam uns aos outros para poderem entrar na sala de aulas; de tal modo que também o grande auditório de filosofia não tinha capacidade para conter tanta gente" (2, pág. 74).

Em Erfurt casou-se Hessus no ano 1515 com uma mulher de boa linhagem, Catarina Spatarin, após sérias dificuldades com o pai dela, que se opunha ao casamento. Viveu ainda algum tempo a sua vida de casado, conhecendo os prazeres ligados ao lar e lidando com seus filhos.

Casou-se ainda Hessus mais três ou quatro vêzes e foi do seu segundo ou terceiro casamento que nasceu o futuro co-fundador do Rio de Janeiro.

Disturbios nos círculos estudantis e a guerra dos camponeses tinham gravemente afetado Erfurt e especialmente a Universidade. Hessus começou então a estudar medicina, com a esperança de melhorar o seu nível de vida através de uma profissão prática. Porém nunca chegou a exercê-la, tendo-se-lhe oferecido uma posição em Nuremberg, de grande prestígio e que parecia oferecer boas perspectivas. Para aquela época, os vencimentos eram verdadeiramente bons e além disso a estada na rica e artística cidade de Nuremberg era muito agradável, de modo que assim os seis anos que ali viveu pertencem ao período mais feliz de sua vida. Associou-se estreitamente a muitos cientistas, poetas e artistas, vereadores e homens de negócios. Dürer pertencia ao número dos seus amigos e foi Eobanus Hessus quem escreveu um in memoriam quando o grande pintor alemão fechou os olhos para sempre em 6 de abril de 1528; e foi também Hessus quem pronunciou a oração fúnebre quando o artista foi enterrado ( 8 , pág. 226). Sob pressão de seus amigos de Erfurt, porém, que esperavam o ressurgimento da Universidade com a sua presença naquela cidade, foi contra a sua própria vontade que Hessus se despediu de Nuremberg e, pela terceira vez, mudou a sua residência para Erfurt. Precisamente nessa altura, mas já demasiado tarde, o eleitor da Saxônia ofereceu-lhe o professorado de poesia em Wittenberg. Infelizmente, as esperanças de que o regresso de Hessus a Erfurt despertaria uma nova vida acadêmica na Universidade não se materializaram. A Universidade, em vez de se rejuvenescer, perdeu cada vez mais a perspectiva de maior atividade, e o sábio sentiu-se feliz quando, decorridos quatro anos, um convite do seu soberano de Hesse para fixar residência em Marburgo livrou-o de uma situação difícil. Em Marburgo,

"êle encontrou o que desejava. O seu bem-estar aumentou, assim como a expressão da sua sabedoria, de ano para ano. $O$ seu príncipe estimava-o, apreciando o seu valor; encontrava nêle a boa 
disposição e da sua companhia colhia muito prazer; muitas vêzes o convidava para a sua mesa e conversava com êle acêrca das questões e assuntos da época. Como Eoban era um bom jogador de xadrez e o príncipe divertia-se muito com aquêle jôgo de cavaleiros, e como o sábio jogava mais para um descanso mental e assim nem sempre lhe prestava a atenção que era devida, o príncipe regozijava-se quando derrotava um homem tão erudito e de tão rara inteligência, e por isso com muito gôsto o convidava freqüentemente para jogar com êle. A atenção do príncipe para com o poeta deu a êste uma qualidade de destaque perante os seus concidadãos, e assim todos se esforçavam por conhecê-lo pessoalmente, e as mais distintas famílias consideravam-se felizes em o ter como amigo. Ele próprio levava uma vida sossegada no seio da família. Sem ser verdadeiramente rico, não tinha quaisquer preocupações no que dizia respeito a necessidades; pouco depois passou a receber um aumento de subsidio do decanado de São Goar que the dava também direito a duas boas carradas de vinho, e as promessas do príncipe ofereciam boas expectativas para o futuro" (2, pág. 215-216).

Eoban e Lutero davam-se muito bem e Eoban pertencia ao grupo de promotores das novas doutrinas religiosas; Erfurt considerava-o um dos seus reformadores. Também em Marburgo êle teve a oportunidade de esforçar-se em prol do evangelho e em 1537 seguiu para Schmalkalden para uma assembléia das côrtes coligadas.

"Eoban passou os seus últimos anos de vida dedicando-se à poesia e a trabalhos de grande erudição em Marburgo; mantendo ao mesmo tempo uma correspondência muito ativa com os seus ilustres amigos, e com os colegas de Erfurt... A sua vida privada decorria sossegada e despreocupadamente, mas era êle às vêzes torturado por dores derivadas do mal de que padecia (gôta) que muito o fizeram sofrer principalmente no último ano da sua existência. Mas, através da sua disposição corajosa, conseguiu suportar essas dores. Ele tinha-se de fato apercebido do mal, da doença que pensava ter afastado mas que, contra tôdas as suposições, o voltou a atacar. Sentia a morte aproximar-se, mas guardou êsse segrêdo e escondeu o perigo da mulher e dos amigos. Morreu em 5 de outubro de 1540 , após uma vida de grande atividade e muita glória. Não tinha atingido 54 anos... O príncipe seu amigo sofreu muito com a notícia da morte de Hessus. E chegou à conclusão de que um tão grande sábio não pederia ter deixado muitos bens materiais à sua família, isto é, além da glória e da fama. E assim tomou as medidas necessárias para que à familia do seu amigo nada faltasse, mesmo após a sua própria morte. Os filhos do poeta foram recolhidos na sua côrte, a viúva e as filhas foram entregues à proteção de sua espôsa; e determinou-se que todos êles seriam apoiados e protegidos de qualquer preocupação cu necessidade, para o presente e para o futuro" (2, pág. 224-226). 
O antigo pregador em Marburgo e amigo de Eobanus, Joh. Draconites, referiu-se ao falecido no seu sermão fúnebre,

"que êle tinha escrito a palavra divina tão puramente e de maneira tão sonora, como nenhum outro poeta sôbre a terra".

\section{III}

Foi pormenorizadamente que apresentamos a vida e carreira do humanista Helius Eobanus Hessus, o pai do co-fundador do Rio de Janeiro, principalmente os últimos anos e cremos que a justificação para isso encontra-se no fato de querermos apresentar uma precisa compreensão, um melhor conhecimento do ambiente no qual decorreu a infância do homem que foi para o Brasil - a atmosfera da sua casa paterna, o ambiente espiritual que o formou, tudo isso é impres. cindível se queremos dar movimento e vida ao seu retrato. $O$ seu pai pertenceu aos mais importantes intelectuais do seu tempo; as mais distintas personalidades da vida espiritual, intelectual, artística e política entravam e saíam da sua casa paterna ou pertenciam ao número dos amigos do seu pai: homens de posições elevadas e príncipes distinguiam o poeta com sua companhia, e êle, como é testemunhado, era um pai carinhoso e dedicava-se à educação dos seus fithos - do que se conclui que o nosso Heliodor Eobano foi instruído pelo seu pai nas ciências .

Quando ainda não tinha atingido quatro anos de idade. Heliodor deixou Nuremberg, a sua cidade natal; a época decorrida em Nuremberg não pode por conseguinte ter tido qualquer influência sôbre êle. A estada em Erfurt e, em seguida, em Marburgo, foram certamente parte determinante da sua infância; sôbre os anos passados em Erfurt pairaram as sombbras da decadência da Universidade, as preocupações financeiras no lar paterno, e da longa permanência, logo no início, no campo, devido à peste. Marburgo, porém, deve ter impressionado o rapaz como uma época feliz e despreocupada, até a morte de seu pai; as impressões colhidas nesta cidade universitária foram de certo inconfundíveis e duradouras. O comentário de Lossius acêrca do que o príncipe tinha feito após o falecimento do sábio, das medidas que tinham sido tomadas para a proteção e apôio da família, do acolhimento dado aos filhos na côrte, dá-nos o conhecimento de que Heliodor passou pelo menos um ano, até à matrícula na Universidade de Marburgo, no ambiente daquela côrte, perto do príncipe, e assim adquirindo maneiras de cortesão. Possìvelmente teria êle, com a sua madrasta e irmãos, passado algum tempo na chacara em Kaldern, propriedade essa que tinha sido doada ao poeta 
pelo príncipe, uns quatro dias antes da morte daquele. Mas em 1541 já se encontrava Heliodor novamente em Marburgo: pois tinha-lhe sido concedida uma bôlsa por quatro anos; quando se matriculou na Universidade, tinha êle uns escassos 13 anos de idade. Nessa mesma altura, o seu irmão Július foi nomeado para escrivão de chancelaria em Cassel. Terminada a bôlsa, parece que Heliodorus Hessus, como êle se chamava na Alemanha, foi imediatamente colocado ao serviço do príncipe; pois em 1546 encontrava-se êle entre os escrivães da secretaria da guerra, durante a campanha do Danúbio. Assim se habituou, embora trabalhasse na' seção administrativa, às coisas e assuntos militares e conheceu a guerra de perto. Segundo um decreto do príncipe, de 13 de julho de 1547, Hessus e os seus colegas da secretaria da guerra deviam ser despedidos. A chancelaria foi dissolvida logo após o infeliz sucesso da campanha; $\mathrm{He}-$ liodorus devia, porém, como a ordem do príncipe indicava, ocupar uma outra posição. Durante essa época, e provàvelmente mesmo antes, era o jovem Hessus, durante anos órfão, filho adotivo de Hans Rommel. Não se sabe se a êle foi logo a seguir dado nôvo cargo; segundo Krause (4, pág. 261) êle devia ter seguido para a Holanda em 1548; em fins de 1552 Hans Staden encontrava-se com êle em São Vicente (9, pág. 50). Krause refere-se ainda a um documento dos arquivos de estado de Marburgo, segundo o qual

"Hans Rummel, registra que o seu filho adotivo, Heliodorus Hessus, sem a sua auterização, tinha levantada na Holanda uma quantia de 125 Reichstaler como parte da herança a que tinha direito" (4, pág. 261).

Infelizmente o biógrafo do professor de Marburgo não dá nenhuma data dêsses acontecimentos.

"Do patrimônio em Kaldern, que após da morte da viúva do sábio, entre 1541 a 1543, foi arrendado, o jovem Heliodorus tinha provàvelmente direito a uma receita ou rendimento. Continuou até 1558 a ser propriedade da família, quando, como uma comunicação do conselheiro de igreja D. Grimmell informa, foi vendido por Galimachus, um irmão daquele que foi para o Brasil".

A situação incerta em que a terra de Hesse se encontrava após o fim da Guerra de Schamalkalden, possivelmente impossibilitou uma nova colocação para Heliodorus.

"O infeliz sucesso da guerra para o príncipe Filipe, o seu aprisionamento em Halle a 19 de junho de 1547 , a forçada entrega da sua artilharia ao imperador Carlos $\mathrm{V}$ e a pressão da ocupação pelas tropas imperiais, entre as quais tropas espanholas, podia ter sido a 
causa da viagem tanto de Heliodorus Hessus como de Hans Staden, possivelmente no mesmo ano, 1548, para terras estrangeiras" (10, pág. 9).

Talvez tivesse também havido um alheamento entre Heliodorus e o seu pai adotivo, como a informação de Krause faz suspeitar. Muito deve ter acontecido para êle deixar a pátria. Também autores brasileiros têm procurado as causas da sua saída da terra natal. Não raras vêzes chegavam ao ponto em que suspeitavam que o jovem alemão teria sido levado à América do Sul pelo seu fervor religioso, perseguido pelos luteranos. Um historiador deu asas à sua imaginação e escreveu que Hessus se tinha refugiado primeiramente em Gênova, depois em Portugal e finalmente encontrado refúgio no barco do genovês Adôrno, que o levou para o Brasil (11, pág. 420). Ermelino de Leão foi de certo levado a essa tese audaciosa pelo fato de ter Hans Staden encontrado seu conterrâneo em São Vicente, segundo êle escreve, como

$$
\begin{aligned}
& \text { "escriturário e pagador dos comerciantes que pertenciam ao } \\
& \text { engenho" }
\end{aligned}
$$

- engenho, que era de José Adôrno. E' todavia surpreendente que Heliodorus se tivesse empregado e procurado emprêgo no engenho de cana-do-açúcar dos Adôrnos, que tinham vindo de Gênova e não no engenho dos Erasmos, que pertencia a flamengos e tinha sido administrado por um conterrâneo, Peter Rössel. Esse moinho de cana-do-açucar, possìvelmente o mais velho e conhecido de todo o território brasileiro, foi adquirido em 1540 por Erasmus Schetz e alguns sócios. Schetz pertencia a uma família alemã de comerciantes que se tinha radicado em Antuérpia e que desde 1520 pertencia, aliás, ao lado dos Fugger e dos Welser e de vários outros, aos mais distintos comerciantes entre os alemães e baixo-alemães da época, mantendo um banco, numerosas feitorias dentro e fora do Império Alemão e, no Brasil, plantações de cana-de-açúcar e um engenho para o mesmo produto. Erasmus Schetz, o chefe da firma. não gostava, porém, de ser sòmente banqueiro e comerciante; êle era ao mesmo tempo um intelectual de grande cultura, que se encontrava relacionado com os mais distintos representantes do humanismo na Europa, e assim também com Helius Eobanus Hessus. E' bem provável que o jovem Hesse se tivesse lembrado dessa ligação e na Holanda tivesse ido ter com Schetz, e possivelmente recebido do banco do amigo do seu pai 125 Talers por conta do seu patrimônio pois sem uma ligação pessoal não haveria de certo qualquer comerciante que entregasse uma quantia bastante avultada como essa a um jovem ainda sob tutela. Também não é improvável que inicial- 
mente Heliodor se tivesse empregado no moinho de cana-de-açúcar dos Schetz em São Vicente, e um alheamento começou a se fazer sentir sòmente após o seu pai adotivo Hans Rommel ter informado o banqueiro de que o jovem Hessus não tinha sido autorizado a se ausentar do país para a Holanda ou qualquer outro país e a pedir um empréstimo sôbre o seu patrimônio. Talvez o documento acima mencionado, do pai adotivo, pudesse, na sua forma integral e exata, trazer os esclarecimentos. E' também notável que o Prof. Dr. Johann Eychmann, chamado Dryander, que entrou como professor na Universidade de Marburgo pouco mais ou menos ao mesmo tempo que Helius Eobanus Hessus, escreveu um prefácio bastante extenso para o livro de viagens de Hans Staden, no qual dizia,

\footnotetext{
"Heliodorus o filho do culto e famado Eobanus Hessus", "já há muito tempo no estrangeiro" "foi por nós considerado morto" (9, pág. 12).
}

A estreita e regular ligação entre a firma Schetz em Antuérpia e a povoação de São Vicente permitiu transmitir notícias, para aquela época muito ràpidamente; ter-se-ia sabido na Europa que Heliodor, que entretanto tinha conseguido uma boa colocação, continuava a viver na América. Após a morte de Erasmus Schetz (1550) tôdas as ligações entre Antuérpia e Marburgo provàvelmente foram desfeitas; e depois do incidente desagradável que precedeu à viagem do jovem Hessus para o estrangeiro provàvelmente ninguém sentia prazer em continuar a colher notícias na própria firma Schetz. Existem também dúvidas a respeito dos outros membros da família Hessus: viveria ainda algum dêles em Marburgo? Krause escreve acêrca dos filhos do poeta:

"Os dois mais velhos, Hyeronimus e Július, encontraram após a morte do pai uma ocupação no serviço do príncipe, mas os seus nomes, assim como o da sua irmã Novica, acabaram por desaparecer" (4, pág. 261).

Nas indicações precedentes esgotam-se na substâncias os fatos até agora revelados sôbre a vida de Heliodorus Hessus antes da sua chegada ao Brasil. As fontes tornam-se escassas; resta-nos esperar que os arquivos na Alemanha possam fornecer mais pormenores que contribuam para completar o esbôço e esclarecer dúvidas. Não há ainda uma verdadeira investigação alemã do caso de Heliodor Hesse; além das informações de Krause (4) e várias indicações extraídas da obra de Franz Gundlach Die hessischen Zentralbehörden von 12471604, publicada em Marburgo em 1930, que o pastor e investigador de história Martin Begrich, residente anteriormente em São Paulo, tentou obter, assim como várias indicações que D. Grimmell extraíu 
do arquivo genealógigo de Marburgo, não há até hoje absolutamente nada (12). Este material foi completado ainda através de informações que o autor deve principalmente a Lossius (2) e à Biografia Geral Alemã (5). Ainda assim é bastante superior àquilo que uma investigação intensiva sôbre Staden pôde revelar sôbre a vida do artilheiro de Homberg, antes e depois da sua estada no Brasil. Impõe-se uma comparação com Hans Staden. O seu relato revela de maneira convincente a índole e mentalidade do prisionciro de Ubatuba; Heliodor Eoban não nos deixou quaisquer apontamentos; as conclusões sôbre as suas qualidades de caráter são assim baseadas nas importantes missões de que foi encarregado e nos altos postos que lhe foram confiados. O que para nós aproxima os dois alemães é a sua ligação à terra de Hesse, são as suas relações com Marburgo, as suas partidas provàvelmente no mesmo ano para o Brasil e a sua estada na mesma região (São Vicente-Rio de Janeiro). Os quatro anos e dois meses que Staden permaneceu no Brasil (9, pág. 164) foram, com a exceção dos três meses em Pernambuco e o ano em Bertioga, mais de sofrimento do que de ação, pois a sua importância para o Brasil não se baseia no papel que desempenhou na vida pública da jovem colônia portuguêsa, mas sim no valor do seu relatório de viagem para os mais variados ramos do conhecimento do Brasil. O nome de Staden foi transmitido à posteridade sòmente através do seu livro. Não existe ao que saibamos um só documento brasileiro que o mencione. O mesmo não acontece com Heliodorus Hessus; os serviços diretos por êle prestados ao país são notáveis; já em São Vicente a sua reputação estava firme, pois se assim não fôsse não the teriam confiado o comando de tropas auxiliares, e a posição que lhe cabia nas primeiras décadas após a fundação na vida pública do Rio de Janeiro era proeminente.

Um só outro alemão desempenhou no Brasil, no século XVI, um papel comparável ao de Heliodoro Hesse. Christoph Lins em Pernambuco, Alagoas e Paraíba. A instrução que Staden recebeu foi, como hoje sabemos, boa, mas não científica. Deve-se supor que Heliodorus Hesse já na casa paterna fôra iniciado em ciências e nas línguas clássicas, pois se assim não fôsse êle não teria podido ingressar na Universidade com pouco mais ou menos 13 anos de idade. No que diz respeito à cultura deve êle ter sido o mais distinto alemão que no primeiro século da história do Brasil ali se estabeleceu, fato que o qualificou a ocupar postos de grande importância.

O filho do professor universitário de Hesse, que foi impelido para a Terra de Santa Cruz, adotou aqui para seu uso um nome dife- 
rente do que usava na Alemanha: em vez de Heliodor Hesse ou Heliodorus Hessus, passou a usar Heliodoro Eobano. E' possível que o tivesse feito para que em português se não dissessc, entendesse e escrevesse "Eça" em vez de Hesse. Escriturários não habituados a nomes estrangeiros encontravam mesmo assim dificuldades na soletração e assim faziam erros que mutilavam e transformavam o nome, adaptando-o aos sons da língua a que estavam acostumados. Eleodoro Ebano, Eleodoro Ebanos, Eleodoro Eobano, Eliodoro d'Ebano, Eliodoro Ebano, Heleodoro Ebano, Heleodoro Ebanos, Heleodoro Esbanos, Heliodoro de barros, Heliodoro Ebano, Leador Abanos, Leodoro allamão, Leodoro Eobano, Leodano de Oband, Leodoro Ebanos, Liador Abanos, Liodor abanos, Lyador Abanos, Oleodoro Eobano, Theodosio Ebano, Tehotonio Ebano, são grafias que ocorrem em documentos, que se referem a Heliodoro Eobano, nome que usaremos para designar o alemão daqui por diante, ou a descendentes homônimos do mesmo. Mais tarde, já no fim do século XVII, surgem sucessores dêsse nome, com a grafia Evanos. Na literatura brasileira encontramos com freqüência o nome de Heliodcro Eobano na forma correta ou uma das acima mencionadas. E êsses nomes aparecem ligados a acontecimento e ações separados uns dos outros por tempo e espaço.

Guarda-livros e administrador do engenho São João. que pertencia aos Adôrnos, hoje no âmbito da cidade de Santos; administrador da refinaria de açúcar de Schetz em São Vicente; o primeiro ou um dos primeiros bandeirantes que exploraram o interior e o sul do território, o primeiro ou um dos primeiros descobridores de minas de ouro; chefe de tropas auxiliares vicentinas que, em 1560, 1565 e 1567 , avançaram para a baía de Guanabara para expulsar os franceses; co-fundador do Rio de Janeiro; fundador de Iguape, Paranaguá e Curitiba; capitão ou almirante das fôrças da marinha no sul do país; fundador de uma fundição de ouro no Paraná; negociante de pau-brasil no Rio; em 1568 e, finalmente, 1582, escrivão real da fazenda no Rio; ali vereador em 1569 e juiz até 1574; morto em combate em 8 de junho de 1567, 1568, ou 1569 no Cabo Frio, em luta contra os franceses: estas são - verdadeiras ou falsas -- as informações que se ligam ao nome de Heliodoro Eobano, além de outras associadas a datas que não podem corresponder ao alemão - que já não se encontrava entre os vivos ou era então demasiado velho para exercer os cargos indicados.

Mas com o mesmo fervor com que os cronistas atribuíam a Heliodoro atos e postos distintos, também foram os mesmos negados ao alemão. Os velhos historiadores não se preocupam muito com datas em relação aos acontecimentos, e o fato de o nome Heliodoro li- 
gado ao de Eobano, que se tornou apelido de família, repetir-se durante gerações, levou a equívocos. As confusões aumcntam constantemenete e quando, 200 anos após a época de Hessus, o historiador paulista e linhagista Pedro Taques de Almeida Paes Leme decide juntar o nome de Pereira ao do primeiro Heliodoro Eobano, mais complexo se torna o assunto: segundo êste geneologista, Heliodoro teria pertencido à família do fundador do Rio de Janeiro, Estácio de Sá (14). Pedro Taques caíu neste êrro porque êle se familiarizara com os documentos que continham o nome de Ebanos Pereira ou Evano Pereira, que ocorre desde o fim do século XVII em São Paulo, Rio de Janeiro e Minas Gerais e possivelmente conhecia portadores dêsse nome. O parentesco com os Sás, com a "Dinastia Sá", como a respeito dêles se dizia no Rio de Janeiro, ficou tradição da família, devido a ligações posteriores dos Eobano aos Sousa e Pereira. Taques nunca se absteve de contìnuamente usar o nome de Eobano com o de Pereira. Em qualquer dos casos, êste equíívoco era muito conveniente a muitos escritores; e êles, já que um alemão não se poderia apropriadamente chamar Pereira e pertencer à família de Estácio de Sá, imaginaram um português Heliodoro Eobano, c assim a confusão tornou-se ainda maior.

Era um verdadeiro matagal sem clareiras, quando o historiador Ermelino A. de Leão interveio. Ele queria - estimulado por um fervor de ufanismo regional - demonstrar que a exploraçãu do interior do Paraná e a fundação de Curitiba, a capital do estado de hoje, não teria sido realizada em meados do século XVII, mas sim poucos anos após o terceiro quartel do século anterior. Em resumo, a sua argumentação era a seguinte: a figura central do Paraná de então foi, como é notório Heliodoro Eobano; Heliodoro Eobano era alemão; êste alemão nascera em 1530; por isso, não podia descobrir minas de ouro em meados do século XVII, dirigir operações no interior e fundar cidades; todos êstes acontecimentos pertencem portanto à época entre 1570 e 1584, para os quais existiu um Heliodoro Eobano alemão no Rio de Janeiro. O fato de todos os documentos, até agora tornados conhecidos, que têm ligação com o nome de Eleodoro Eobano e ao Paraná, pertencerem sem exceção, às quarta e quinta décadas do século XVII, de nenhum modo o contrariara. Infelizmente outros historiadores, entre os quais alguns de grande e merecido renome, não põem em dúvida as afirmaçõcs de Leão e aceitam as suas conclusões. Basílio de Magalhães, por exemplo, em edições posteriores do seu notável trabalho sôbre a cxpansão geográfica do Brasil, abandona a descrição correta dos acontecimentos contida na primeira edição, para endossar as conclusões falhas de Leão (15). Também autores de obras em alemão caem no mesmo 
êrro, aceitando a teoria de Leão. Assim, escreve Friedrich Sommer em 1936:

\footnotetext{
"Nós preferimos aceitar a sua (de Leão) opinião, em oposição a Helmut Andrä, segundo o qual Eleodoro Ebano Pereira teria sido uma outra pessoa, quando muito um descendente de Heliodoro" (16, pág. 51).
}

Depois de terem trazido à cena ainda um Heliodoro Eobano português, ficaram ainda mais baralhados os acontecimentos em Santos, São Vicente e Rio de Janeiro, nos quais Heliodoro constituía a figura central. Ora casaram aquêle alemão ou português, em São Vicente ou no Rio, com uma filha do afamado João de Sousa Pereira Botafogo, ora deixaram um ou outro descobrir uma ou mais minas e consentiram que êste ou aquêle comandasse tropas auxiliares nas operações do Rio de Janeiro, deixaram-nos depois morrer em Cabo Frio nos combates contra os corsários franceses, ou sobreviver para ocuparem cargos distintos como os de vereador, juiz ou escrivão real. Dom Clemente Maria de Silva-Nigra, que nos seus estudos da arte sacra também se refere a Heliodoro, consultou a respeito o mais eminente historiador do Brasil de então, Afonso de E. Taunay, que em 1950 the respondia:

"A história dos vários Eliodoro Eobano ou Ebano pertence às mais confusas, há lacunas que serão muito difícil de preencher" (17, pág. 12).

Uma resposta semelhante recebeu também o autor dêste artigo, quando, há cêrca de 25 anos, ainda no início da sua preocupação com o caso de Heliodoro Eobano, procurou o historiador das entradas dos bandeirantes.

Não são raras as vêzes, infelizmente, em que historiadores modernos, em vez de considerar crìticamente a documentação existente, preferem acrescentar-lhe ainda fatos não comprovados e tornam mais confuso o assunto. Carvalho Franco foi ainda mais longe dando a ambos Heliodoros Eobanos, o alemão e o português, domicílio em São Vicente, levando ambos à campanha de reconquista do Rio, confiando, é verdade, o comando ao alemão, deixando-o porém $\in \mathrm{m}$ seguida morrer pelo Brasil em 1568, em Cabo Frio, enquanto o português começa uma vida brilhante na posterior capital brasileira (18, págs. 192 e 140). Carvalho Franco considera, aliás, prudente distingüir um do outro nos nomes, chamando ao alemão Eleodoro Hessus e ao português Eleodoro Ebanos; ignorando, todavia, que o nome da família Hessus aparece ligeiramente aportuguesado sòmente num único documento luso-brasileiro contemporâneo que teve a ori- 
gem na época em que êle estava em São Vicente-Santos (13) e que, segundo as fontes até agora reveladas, não houve na região do Rio de Janeiro ou do Paraná um Eleodoro Hessus ou mesmo Heso. Continua também a ser estranho nesta interpretação que um familiar íntimo do governador geral português e do fundador do Rio de Janeiro, a quem, segundo a variante de Carvalho Franco, tinham sido confiados postos elevados desde 1568, seja um simples lanquesné que toma parte na expedição de São Vicente ao Rio em 1565 sob o comando de Hessus, evidentemente sem missão determinada, de certo modo como um observador de batalhas, e quem também fique no Rio de Janeiro, num plano secundário, modesto e discreto.

Semelhantes disparates podem também ser verificados nas obras de outros autores modernos, mas basta êste exemplo. De modo nenhum insignificante contribuíram para esta enorme confusão o benemérito historiador paulista do século passado, Azevedo Marques (19, pág. 179) e o cronista fantasista da Companhia de Jesus; o padre Simão de Vasconcellos (20) que pertence ao século XVII. Os dois primeiros verbetes da obra de Azevedo Marques, sob a letra $\mathrm{H}$, ocupam-se de Hans Staden e Heliodoro Euban. Sôbre Staden diz o autor que êle se tinha instalado em casa do seu conterrâneo e Heliodoro Euban e refere-se a seguir, entre parênteses, ao apontamente seguintc, mas neste escreve:

\footnotetext{
"Heliodor Euban, natural de Portugal, primo-irmão de Estácio de Sá, o fundador e conquistador do Rio de Janeiro".
}

Um confrônto dos elementos acessíveis, a sua comparação objetiva e uma revisão dos acontecimentos e feitos ditos como fatos resultam nas conclusões seguintes:

1) Não se assinala qualquer português de nome He!iodoro Eobano ou Eleodoro Ebanos, nos relatórios e documentos luso-brasileiros do século XVI;

2) Para o Brasil antigo, o nome de Heliodoro Eobano serve meramente para demonstrar a presença de um alemão que na sua terra de origem se chamava Heliodorus Hessus ou Heliodor Eoban Hesse;

3) O Heliodoro Eobano que, segundo documentos, teve no Rio de Janeiro, nos anos 1568 até 1585, os cargos de escrivão real, juiz, vereador e negociante de madeira (pau-brasil), deve ter sido, contando que não haja contraprovas conclusivas, o filho do professor de Marburgo, pois sòmente a presença dêle no Rio daquele período é documentada como também a sua cultura e instrução, extraordinárias no Brasil de então, o poderiam habilitar para os cárgos de escrivão real e juiz, especialmente porque os seus estudos na Univer- 
sidade de Marburgo, o que ainda se poderia esclarecer, lhe tivessem sido úteis principalmente para a última profissão;

4) Um Heliodoro Eobano não morreu em combate contra os franceses em 8 de junho de 1568, em Cabo Frio; um simples soldado, chamado Heliodoro Eobano, talvez um filho do alemão, foi morto durante uma emboscada, num ataque na região de Cabo Frio, provàvelmente em 1616 ;

5) Não foi o alemão Heliodoro Eobano que se casou, no Rio de Janeiro ou em São Vicente, com uma filha do muito conhecido Botafogo, antes, como se pode presumir, o seu filho acima referido (21);

6) Heliodoro Eobano foi provàvelmente o primeiro alemão conhecido que se enraizou no Brasil e aqui constituíu família, pois foi muito mais tarde que o primeiro Lins se domiciliou em Pernambuco, entre 1566 e. 1572, como o autor há já dezenas de anos supôs; com base numa comparação crítica das fontes acessívcis, um? suposição que recentemente foi confirmada (23, pág. 319);

7) A combinação dos nomes Eobano Pereira, Ebanos Pereira ou Evanos Pereira surge primeiramente no século XVII, mas mesmo então não com os nomes Heliodoro, Heleodoro ou Eleodoro;

8) O alemão Heliodoro Eobano não pode ser accito como fundador de Curitiba, explorador de minas do Paraná e chefe de expedições ao interior do atual estado; êstes acontecimentos pertencem, como agora não podemos pôr em dúvida, a uma época posterior (22). O indivíduo Eliodoro Ebano que é referido nos documentos relativos aos anos de 1641 e 1652 deve ter sido neto do primeiro Heliodoro Hessus. Não aparece registrado nos documentos referentes ao Paraná um Eliodoro Ebano Pereira; o nome dado a uma rua do centro de Curitiba, em honra do fundador da cidade, Ebano Pereira, é completamente errado; nunca houve uma personalidade dêsse nome ligada a acontecimentos naquela região;

9) A notável participaão do alemão Heliodoro Eobano como comandante de 300 homens das tropas auxiliares de São Vicente, por ocasião da reconquista da Baía de Guanabara, justifica, sem qualquer dúvida, a opinião de muitos autores brasileiros de ver nêle um co-fundador da cidade do Rio de Janeiro; o papel por êle desempenhado na vida pública durante cêrca de 20 anos na cidade que depois se tornou a capital brasileira, permite-nos considerá-lo uma das mais importantes personalidades dos primeiros tempos da sua história.

Chegamos ao fim da nossa investigação; dentro dos limites de um artigo, não era possível acompanhar, seguir, e onde necessário, refutar com tôdas as nossas fôrças as numerosas contradições, deturpaçōes e disparates que no Brasil se ligam à pessoa de Heliodoro Eobano. Isso 
deve ser reservado para um trabalho mais desenvolvido, para o qual são precisos mais pesquisas nos arquivos em Portugal e na Alematha. Seria desejável uma comparação da caligrafia do escrivão da secretaria de guerra de Hesse, Heliodorus Hessus, com a daquele chamado "Leodoro allamão", ou Lyador Abanos, do processo contra Bolés, e de Heliodoro Eobano, escrivão e juiz no Rio de Janeiro.

Talvez estas linhas venham a mover os pesquisadores da terra de Hesse a se dedicarem ao assunto de Heliodorus Hessus. Infelizmente por ocasião das celebrações do $400^{\circ}$ aniversário do Rio de Janeiro, em 1965, não foi devidamente lembrado o bravo e distinto filho do professor universitário e humanista alemão Helius Eobanus Hessus, tanto pelo lado alemão como pelos descendentes de alcmães no Brasil.

\section{ANOTAÇÕES}

1) Begrich, Martin: Villegaignon und die Hugenotten in der Guanabarabucht (Villegaignon e os huguenotes na baía de Guanabara). In: Staden-Jahrbuch, Vol. 5, S. Paulo, 1957.

2) Lossiur, Kaspar Friedrich: Helius Eoban Hess z und seine Zeitgenossen (Helius Eoban Hesse e os seus contemporâneos). Gotha, 1797.

3) Schwartzell, G.: Helius Eobanus Hessus, ein Lebensbild aus der Reformationszeit (Helius Eobanus Hessus, uma biografia da época da Reforma). Halle, 1874.

4) Krause, C.: Helius Eobanus Hessus, sein Leben und seine Werke (Hessus, a sua vida e as suas obras). Dois Volumes, Gotha, 1879.

5) Geiger, Ludwig: Helius Eobanus. In: "Allgemeine Deutsche Biographie", Vol. 12, Leipzig, 1880, págs. 316-319.

6) Erasmus von Rotterdam: Briefe (Cartas). Edição da "Deutsche BuchGemeinschaft", Darmstadt.

7) Stahr: Marburger Sippenbuch (Prontuário genealógico de Marburgo).

8) Steck, Max: Albrecht Dürer, Schriften - Tagebücher - Briefe. (Albrecht Dürer, Escritos - Diários - Cartas). Stuttgart, 1961.

9) Staden, Hans: Zwei Reisen nach Brasilien (Duas viagens ao Brasil). Marburgo, 1963.

10) Fouquet, Karl: Hans Staden und sein Reisewerk (Hans Staden e o seu relatório de viagens). In: Staden Jahrbuch, vol. 5, São Paulo, 1957.

11) Leão, Ermelino: Heleodoro Eobanos, na Revista do Instituto Histórico e Geoegráfico de São Paulo, Vol. XIII, São Paulo, 1911, págs. 415-434.

12) As obras designadas sob (3), (4) e (7) não estiveram ao dispor do autor para sua consulta; agradece aos srs. pastor Martin Begrich, anteriormente em São Paulo, e ao membro do conselho da igreja de Cassel, D. Grimell, pelos extratos que foram usados neste trabalho.

13) O jovem alemão tentou primeiramente continuar a usar no Brasil o nome Hessus ou Hesse, tornado famoso por seu pai. O padre jesuíta Luís da Grã designa como testemunha, numa petição, um Lyador Heso (esta a maneira de escrever do copista). Conf.: Petição do Provincial Luís da 
Gră de 22 de abril de 1560. In.: Serafim Leite S. J., Cartas dos primeiros jesuítas do Brasil. Vol. III (1558-1563). São Paulo (1958), pág. 181.

14) Taques de Alméida Paes Leme, Pedro; a) História da Capitania de São Vicente. S. Paulo, s. a.; b) Nobilarchia Paulistana. In: Revista do Instituto Histórico e Geográfico Brasileiro, tomo especial, Rio, 1926.

15) Magalhães, Basílio de: Expansão Geográfica do Brasil Colonial. 3a. edição, Rio, 1944.

16) Sommer, Friedrich: Beiträge zur Siedlungs-, Sippen- und Familiengeschichte der Deutschen in Brasilien (Contribuiçōes para a história da colonização, da genealogia e das famílias dos alemães no Brasil). In: Volk und Heimat, Kalender für das Deutschtum in Brasilien, São Paulo, 1936.

17) Silva-Nigra, Dom Clemente Maria da: Construtores e artistas do mosteiro de São Bento do Rio de Janeiro. Salvador, 1950.

18) Carvalho Franco, Francisco de Assis: Dicionário de Bandeirantes e Sertanistas do Brasil. São Paulo, 1954.

19) Azevedo Marques, Manoel Eufrázio de: Apontamentos históricos, geográficos, estatísticos e noticiosos da província de S. Paulo, Rio de Janeiro, 1879.

20) Vasconcelos, Simão de: a) Chronica da Companhia de Jesus do Estado do Brasil. Lisboa, 1643; b) Vida do Venerável Padre José de Anchieta, 2 vols. Rio, 1942.

21) O autor agradece ao conhecido historiador Dr. Carlos da Silveira a oportunidade de analisar as fotocópias de documentos genealógicos, que justificaram as opiniōes.

22) Martins, Romário: História do Paraná. 2a. edição, S. Paulo, 1939.

23) Famílias Brasileiras de Origem Germânica. Vol. II, São Paulo, 1963. 